\title{
Antiviral activities of plants occurring in the state of Minas Gerais, Brazil. Part 2. Screening Bignoniaceae species"
}

\author{
Geraldo Célio Brandão, ${ }^{1}$ Erna G. Kroon, ${ }^{2}$ João Rodrigues dos Santos, ${ }^{2}$ João Renato Stehmann, ${ }^{3}$ \\ Júlio A. Lombardi, ${ }^{4}$ Alaíde Braga de Oliveira ${ }^{*}, 1$
}

\begin{abstract}
${ }^{1}$ Laboratório de Fitoquímica, Departamento de Produtos Farmacêuticos, Faculdade de Farmácia, Universidade Federal de Minas Gerais, Av. Antônio Carlos, 6627, 31270-901 Belo Horizonte-MG, Brazil,

${ }^{2}$ Laboratório de Virus, Departamento de Microbiologia, Instituto de Ciências Biológicas, Universidade Federal de Minas Gerais, Av. Antônio Carlos, 6627, 31270-901 Belo Horizonte-MG, Brazil,

${ }^{3}$ Laboratório de Taxonomia Vegetal, Departamento de Botânica, Instituto de Ciências Biológicas, Universidade Federal de Minas Gerais, Av. Antônio Carlos, 6627, 31270-901 Belo Horizonte-MG, Brazil,

${ }^{4}$ Departamento de Botânica, Instituto de Biociências de Rio Claro, Universidade Estadual Paulista, Av. 24-A 1515, Bela Vista, 13506-900 Rio Claro-SP, Brazil.
\end{abstract}

\begin{abstract}
RESUMO: "Atividade antiviral de extratos de plantas coletadas no estado de Minas Gerais. Parte 2. Triagem de Bignoniaceae." Extratos etanólicos de dezoito espécies vegetais pertencentes à família Bignoniaceae, das quais sete são descritas como de uso medicinal, foram avaliados, pelo ensaio colorimétrico do MTT, para atividades citotóxica, em células Vero, e antiviral, frente aos vírus herpes simplex-tipo 1, vaccinia e encefalomiocardite murina. A maior parte dos extratos não apresentou citotoxicidade até a concentração de $500 \mu \mathrm{g} / \mathrm{mL}$. Dos 28 extratos testados quatorze (50\%) apresentaram atividade antiviral com valores de CE50 na faixa de 4,6+03 a 377,2+17,7 $\mu \mathrm{g} / \mathrm{mL}$. Somente duas espécies, Arrabidaea samydoides e Callichlamys latifolia, foram ativas frente aos três vírus. Os extratos foram caracterizados pelos seus perfís cromatográficos em CCD e CLAE-FR. Análises por CLAE-FR mostraram que a mangiferina é o constituinte majoritário em $A$. samydoides mas a substância isolada foi menos ativa do que o extrato bruto. Esta é a primeira vez que se relata a atividade antiviral de extratos das dezoito espécies avaliadas.
\end{abstract}

Unitermos: Bignoniaceae, atividade antiviral, citotoxicidade, HHV-1, VACV, EMCV.

\begin{abstract}
Ethanol extracts of eighteen Bignoniaceae species have been evaluated by the MTT assay for cytotoxicity in Vero cells and for antiviral activity against Human herpes virus type 1, Vaccinia virus and murine Encephalomyocarditis virus. Among such species, seven are reported to be of traditional medicinal use No cytotoxicity was observed for most of the extracts up to the concentration of $500 \mu \mathrm{g} / \mathrm{mL}$. Fourteen $(50 \%)$ of the 28 extracts assayed have disclosed antiviral activity with EC50 values in the range of $4.6+0.3$ to $377.2+17.7 \mu \mathrm{g} / \mathrm{mL}$. Only two species, Arrabidaea samydoides and Callichlamys latifolia, have shown activity against all the three viruses. The extracts were chemically characterized by their TLC and HPLC-DAD profiles. Mangiferin is the major constituent of $A$. samydoides but the isolated compound has been less active than the crude extract. This is the first report on the antiviral evaluation of the eighteen Bignoniaceae species assayed.
\end{abstract}

Keywords: Bignoniaceae, antiviral activity, cytotoxicity, HHV-1, VACV, EMCV.

\section{INTRODUCTION}

The marked evolution of biodiversity prospecting has been greatly driven by the growing demand for new genes and chemicals coupled to the awareness that an abundant and virtually untapped supply of natural resources exists in wild land biodiversity. Biotechnology has opened a new frontier in the pharmaceutical industry (Reid et al., 1996). The impact of biodiversity as source of new pharmaceuticals can be appreciated when we consider that a species (plants, microorganisms, animals, and insects) may contain hundreds of different chemicals that might result as new pharmaceutical leads. The success in the discovery of promising lead molecules increased by improvements in screening technology 
that allows evaluation of a high number of compounds at a high speed and relatively low cost (High Throughput Screening - HTS). The progress in this area, associated to advances in synthetic chemistry, biotechnology and medical sciences has led to new drugs in the last 25 years, many of which of plant origin or derived from natural products as extensively shown by Newman \& Cragg (2007). The data presented confirms that the utility of natural products is not necessarily as the final drug entity but also as sources of novel and peculiar molecules to be used for semi-synthetic drugs or templates for totally synthetic ones. Furthermore, besides the important role of natural products as lead compounds in drug discovery, their significance as components of standardized plant extracts provide unlimited opportunities for new medicines. The phytochemical-biological investigation of traditional medicinal plants affords bioactive compounds that, besides their potential as new drug leads, are needed as chemical markers for standardization of extracts to be evaluated for efficacy and safety in the development of phytomedicines (Gibbons, 2003). Phytotherapy, that should be of great importance in developing countries, is still poorly explored, except in countries such as China and India where it is the basis of traditional medicine (TCM and Ayurveda, respectively) or, more recently, in Germany where pythomedicines (phytopharmaceuticals) are legally marketed once there are scientific evidences on their safety and reasonable confidence in their efficacy. That is the so called scientific or rational phytotherapy. Integration of new biological assays into the screening (bioprospection) of plant extracts and in the bioactivity guided isolation of active constituents are prerequisite for the standardization of extracts when the aim is the scientific validation of a medicinal plant used in traditional medicines aiming to investigate their alleged therapeutic use (Schulz et al., 2001).

Aiming to explore the rich Brazilian biodiversity we have started the bioprospection of plants occurring in the state of Minas Gerais, Brazil, by screening plant extracts for antiviral activity.

A large number of antiviral natural products are described (Chattopadhyay \& Naik, 2007). Novel natural anti-HIV compounds, such as the calanolides, michellamines, prostatin and betulinic acid derivatives, have passed through preclinical assays (Butler, 2005). In general, in vitro antiviral assays are based on the cytopathic effect (CPE) in cell culture; in these assays, the activity is expressed by the $50 \%$ endpoint titration technique (EPTT). Over the last two decades, however, the colorimetric MTT assay, in which the MTT dye is reduced by viable cells, is becoming more and more used. This assay is semi- automated, rapid, requires only a small amount of test sample and directly assesses cell viability. (Betancur-Galvis et al., 2002 ).

The present paper reports on the evaluation of the susceptibility of one RNA-virus, the murine
Encephalomyocarditis virus (EMCV), and two DNAviruses, Human herpes virus 1 (HHV-1) and Vaccinia virus Western Reserve (VACV-WR) to ethanol extracts of Bignoniaceae species occurring in the state of Minas Gerais, Brazil. Plants for testing have been selected on the basis of ethnopharmacological and taxonomic criteria. HHV-1 and HHV-2 are pathogenic to humans, causing recurrent infections especially in the case of highly susceptible adults. Among HHV-related pathologies, genital herpes is an important sexually transmitted disease. In immuno-compromised patients and neonates, $\mathrm{HHV}$ infections can cause serious systemic illnesses. Furthermotre, HHV is involved in several ocular diseases, such as the herpetic stromal keratitis (HSK), an immunopathology which is one of the leading causes of blindness in western world. Acyclovir, a nucleoside analogue, is the most commonly used drug for treatment of HHV infections. However, resistance to acyclovir and related nucleosides occurs frequently (Khan et al. 2005) and, therefore, new antiviral agents are needed.

VACV (Poxvirideae family) is in the group of the Poxviruses genus Orthopoxvirus which includes cowpox, vaccinia, variola and camelpox viruses. Vaccinia virus (VV), but not variola virus, was used in the vaccination against smallpox that was eradicated more than twenty years ago. Extensive use of VV for smallpox vaccination, has rendered most humans vulnerable to smallpox infection (De Clercq, 2001). Re-emergence of human VV infections (Trindade et al., 2007) as well the threat that variola virus, the etiological agent of smallpox, might be used in warfare or terrorism, have motivated the search for measures to control or treat smallpox and poxvirus infections, in general. With the eradication of smallpox and the successful application of the smallpox vaccine, the search for new therapeutic agents against smallpox was not further pursued until the late 1970s when a panel of viruses, including VV strains, was evaluated for their susceptibility to different classes of compounds and has led to a large number of anti-VV leads, most of which are nucleoside analogues (De Clercq, 2001).

EMCV (family Picornaviridae, genus Cardiovirus) is a group of closely related virus strains with a wide host range. Infections with EMCV are associated with sporadic cases and outbreaks of myocarditis and encephalitis in domestic pigs, in nonhumans primates and in other mammalian species. The disease is often fatal; frequently sudden death is the first indication of infection and most outbreaks have been associated with captive animals such as those in piggeries, primate research centers and zoos. Virus isolation has been reported from patients with aseptic meningitis, poliomyelitislike paralysis, encephalomyelitis and fever of unknown origin documented by virus isolation of several specimen types. Few cases of human EMCV infection and disease have been documented; the most recent were in 2004 from two febrile patients in Peru (Oberste et al., 2009). 
EMCV was used as a model for RNA virus, especially for viruses from the Picornaviridae family, as it presents a safe animal model to test antiviral drugs (Mujtaba et al., 2006).

Interferons, cell glycoproteins synthesized in response to viral infections and various nonviral inducers, have proved therapeutically effective for viral infections in experimental models and in humans. Their significance as antiviral, antiprotozoal, immunomodulatory and cell growth regulatory agents is well documented. The IFN system can impair various steps of viral replication. However EMC viruses can replicate efficiently in IFNtreated cells what renders these viruses useful in the investigation of compounds whose antiviral effect could be related to stimulation of IFN production. EMCV was also used by our group to study the antiviral activity of interferons (Franco et al., 1999)

A large number of natural products and plant extracts obtained from traditionally used plants has been evaluated against HHV-1 and 2. (Khan et al., 2005). However there are few reports on evaluation of the susceptibility of VACV and EMCV to plant extracts. Many Bignoniaceae species are used in popular (traditional) medicine to the treatment of several diseases. Brazil is the main center of diversity for the Bignoniaceae family with 56 genera and 338 species which are distributed in the tribes Bignonieae, Crescentieae and Tecomeae. (Gentry, 1992 ).

Chemically, bignoniaceous plants are characterized by the presence of flavonoids, terpenoids, quinones, mainly naphthoquinones, and aromatic compounds such as lignans, cinnamoyl, benzoyl and acetophenone derivatives (Warashina et al. 2006). Naphthoquinones occur in many species of the family and could be responsible for different biological activities, including anticancer, antiinflamatory, antiviral, antimicrobial antifungal, antimalarial and antiparasitic. Flavonoids and terpenoids have been shown to disclose a broad spectrum of biological activities including as inhibitors of the cytopathic effect of several viruses (Chattopadhyay \& Naik, 2007). The frequent occurrence of species belonging to the family Bignoniaceae in the state of Minas Gerais and the use of several species in the Brazilian traditional medicine, have motivated the present investigation.

\section{MATERIALS AND METHODS}

\section{Plant material, extraction and chromatographic analyses}

Plant material was collected in the state of Minas Gerais, Brazil. Voucher species were deposited into the herbarium of UFMG (BHCB), Belo Horizonte, Brazil. The plant material was dried in an air circulating oven at $45{ }^{\circ} \mathrm{C}$ for $48 \mathrm{~h}$. The different plant parts were separated, ground and exhaustively extracted by percolation with ethanol $92.8^{\circ} \mathrm{GL}$ affording the crude extracts (Table 1). All the extracts were characterized with TLC as well by HPLC-DAD, with online registration of the UV spectra of the constituents. HPLC fingerprints were registered on a Waters 2695 apparatus with a UV-DAD detector (Waters 2996).

\section{Conditions}

A LiChrospher 100 RP-18 column $(5 \mu \mathrm{m}, 250 \mathrm{x}$ $4 \mathrm{~mm}$ i.d.) (Merck) was employed at a temperature of 40 ${ }^{\circ} \mathrm{C}$, flow rate of $1.0 \mathrm{~mL} / \mathrm{min}$ and detection at wavelengths of 220,280 and $360 \mathrm{~nm}$.

\section{Sample preparation}

To an aliquot $(10.0 \mathrm{mg})$ of each dried extract, HPLC grade $\mathrm{MeOH}$ was added, the mixture was dissolved by sonication in a ultrasom bath for $15 \mathrm{~min}$, followed by centrifugation at $10,000 \mathrm{rpm}$ for $10 \mathrm{~min}$. The supernatant was filtered through Millipore membrane $(0,2 \mu \mathrm{m})$ and injected $(10.0 \mu \mathrm{L})$ onto the equipment. Elution was carried out with a linear gradient of water (A) and acetonitrile (B) (from $5 \%$ to $95 \%$ of $\mathrm{B}$ in $60 \mathrm{~min}$ ).

\section{Isolation and characterization of mangiferin}

To dried ethanol extracts from $A$. samydoides leaves $(10 \mathrm{~g})$ and stems $(10 \mathrm{~g}), \mathrm{MeOH}(30 \mathrm{~mL})$ was added and the insoluble part was filtered of, washed with cold $\mathrm{MeOH}$ and recrystallized from EtOH-water affording mangiferin (leaves extract $0.98 \mathrm{~g}$, stems extract 0.85 g). M.p. $265{ }^{\circ} \mathrm{C}$ (dec.). Mangiferin was identified by usual spectrometric techniques $\left({ }^{1} \mathrm{H}\right.$ and ${ }^{13} \mathrm{CNMR}, \mathrm{IR}$, UV, HRMS) and comparison with reported data (GómezZaleta et al., 2006).

\section{Cell culture and virus}

Kidney cells of the African green monkey Cercopthecus aeothiops (Vero cell line ATCC CCL$81)$ were used in all experiments. Cells were grown in Dulbecco's modified Eagle medium (DMEM), containing $5 \%$ fetal bovine serum, $50 \mu \mathrm{g} / \mathrm{mL}$ gentamicin, $100 \mathrm{U} / \mathrm{mL}$ penicillin, and $5 \mu \mathrm{g} / \mathrm{mL}$ fungizone. The following strains were used in the assays: a clinical isolate of Human Herpes Virus type 1 (HHV-1) obtained in the Laboratory of Virus, Institute of Biological Sciences, UFMG, Belo Horizonte, Brazil, murine Encephalomyocarditis virus (EMCV), and Vaccinia Virus strain Western Reserve (VACV-WR), which were kindly donated by Dr. I. Kerr (Cancer Research UK, London Research Institute, London, United Kingdom) and Dr. C. Jungwirth (University of Würzburg, Germany), respectively. 


\section{Cytotoxicity assay}

Vero cell monolayers were trypsinized, washed with culture medium and plated in a 96-well flat-bottomed plate with 6.104 cells per well. After $24 \mathrm{~h}$ of incubation, the diluted extracts $(800-0.125 \mu \mathrm{g} / \mathrm{mL})$ were added to the wells and the plates were further incubated for 48 $\mathrm{h}$ at $37{ }^{\circ} \mathrm{C}$ in a humidified incubator with $5 \% \mathrm{CO}_{2}$. The supernatants were removed from the wells and $28 \mu \mathrm{L}$ of MTT (Merck) solution ( $2 \mathrm{mg} / \mathrm{mL}$ in PBS) were added to each well. The plates were incubated for $1.5 \mathrm{~h}$ at $37^{\circ} \mathrm{C}$ and DMSO $(130 \mu \mathrm{L})$ was added to the wells to dissolve the formazan crystals. The plates were placed on a shaker for $15 \mathrm{~min}$ and the optical density was determined at $492 \mathrm{~nm}$ (OD492) on a multiwell spectrophotometer (Stat Fax 2100) (Twentyman \& Luscombe, 1987). The results were obtained from four replicates with at least four concentrations of each sample. Cytotoxicity was calculated using the equation (A-B)/A.100, where A and $\mathrm{B}$ are the OD492 values of untreated and treated cells, respectively. The $50 \%$ cytotoxic concentration (CC50) of the assayed samples is defined as the concentration that reduces the OD492 value of treated uninfected cells to $50 \%$ of that of untreated uninfected cells.

\section{Antiviral assay}

The antiviral testing was carried out by the MTT colorimetric assay according to the methodology previously described (Betancur-Galvis et al., 2002). Dilutions of the crude extracts in non-cytotoxic concentrations were added to the wells after viral infection. The plates were incubated at $37{ }^{\circ} \mathrm{C}$ in humidified $5 \%$ $\mathrm{CO}_{2}$ atmosphere for a period of 48 and/or $72 \mathrm{~h}$. Controls consisted of untreated infected, treated non-infected and untreated non-infected cells. Positive controls (acyclovir, Calbiochem, USA; $\alpha$-2a-interferon, Bergamo, Brazil) were also employed in each assay. Cell viability was evaluated by the MTT colorimetric method as described above for the cytotoxicity assay.

\section{RESULTS AND DISCUSSION}

The bignoniaceous species (18) were collected in the state of Minas Gerais, Brazil. The 28 ethanol extracts obtained from different parts have been characterized by their chromatographic profiles on TLC and HPLC (Table 1). All the extracts have been evaluated for cytotoxicity in Vero cell cultures and against HHV-1, VACV and EMCV by the MTT colorimetric assay. (Table 2).

Most of the 28 extracts assayed have not shown cytotoxicity up to the concentration of $500 \mu \mathrm{g} / \mathrm{mL}$ (Table 2). Only two species, Clytostoma ramentaceum and Pleonotoma stichadenium, have been highly cytotoxic with $\mathrm{CC} 50<20 \mu \mathrm{g} / \mathrm{mL}$ and have been more cytotoxic then Tabebuia impetiginosa (synon. T. avellanedae) and
T. serratifolia which are known sources of cytotoxic naphthoquinones (Oliveira et al., 1990).

It is well known that the titer of a virus culture can influence the EC50 in the in vitro bioassays. Plant extracts that are able to protect cells from the induced cytopathic effects (CPE) of a virus with a TCID50/ $\mathrm{mL}>103$ are considered relevant and deserve further investigation for the isolation of the active compounds. In the present screening, assays were run in cultures of virus with TCID $100 / \mathrm{mL}$ of $2.5 \times 106$ for $\mathrm{HHV}-1$, and 1.0 x 106 TCID100/ mL for both VACV-WR and EMCV.

Fourteen $(50 \%)$ of the 28 extracts tested have disclosed antiviral activity against one or more of the virus and have shown EC50 values in the range of 4.6+0.3 to $377.2+17.7 \mu \mathrm{g} / \mathrm{mL}$. Ten of the fourteen active extracts might be considered promising sources of antiviral compounds, as they showed EC $50<100 \mu \mathrm{g} / \mathrm{mL}$ (Table 2).

Nine of the 28 extracts have disclosed activity against HHV-1 (Table 2) and two of these extracts, Arrabidaea samydoides leaves (EC50 40.6+1.6 $\mu \mathrm{g} / \mathrm{mL}$ ) and Callichlamys latifolia stems $(30.4+12.0 \mu \mathrm{g} / \mathrm{mL})$ have shown EC50 values close to that one of acyclovir, a frequently used anti-herpetic drug, besides presenting good selectivity (SI 12.3 and 16.5, respectively). Mangiferin (1), a $C$-glucosylxanthone, and acylated derivatives, characterized as antioxidants by the DPPH assay, were isolated from a specimem of A. samydoides which was collected in the state of São Paulo, Brazil (Pauletti et al., 2003). However no data on the chemistry and biological activity of C. latifolia was found.

We have shown by HPLC-DAD analyses that mangiferin is the major constituent of leaves ethanol extract of the $A$. samydoides specimen and, at a first glance, we might expect its presence would explain the activity of this extract. However, mangiferin (1) is also the major constituent of the stems extract although it has been about five times less active (EC50 218.1+3.4 $\mu \mathrm{g}$ / $\mathrm{mL})$. Therefore, besides mangiferin, other more active compounds are supposed to be present in the leaves of $A$. samydoides and a bioactivity guided fractionation of this extract has to be carried out.<smiles>O=c1c2cc(O)c(O)cc2oc2cc(O)c(Cl)c(O)c12</smiles>

VACV which, as HHV, is a double-streamed DNA virus, has exhibited higher susceptibility to the extracts tested with twelve positive results, seven of these with EC $50<50 \mu \mathrm{g} / \mathrm{mL}$. The most potent of the 28 extracts assayed, with EC50<10 $\mu \mathrm{g} / \mathrm{mL}$, are found in 
this group: Adenocalymma ternatum stems $(8.1+0.4 \mu \mathrm{g} /$ $\mathrm{mL})$ and Distictella elongata leaves $(4.6+0.3 \mu \mathrm{g} / \mathrm{mL}) . A$. samydoides (leaves and stems), Callichlamys latifolia (stems), Distictella elongata stems and Xylophragma myrianthum stems are also promising extracts since they have presented EC $50<50 \mu \mathrm{g} / \mathrm{mL}$.

EMCV was the less susceptible virus species to the extracts assayed. Only one has shown a moderate activity (Callichlamys latifolia stems, EC50 103.0+3.2 $\mu \mathrm{g} / \mathrm{mL}, \mathrm{SI}>4.9)$ and three have been weakly active with EC50>300 $\mu \mathrm{g} / \mathrm{mL}$ (A. samydoides leaves and stems, Adenocalymma pedunculatum stems).

Arrabidaea samydoides and Callichlamys latifolia are the only species among the eighteen tested ones to inhibit replication of HHV-1, VACV and EMCV. The leaves extract of $A$. samydoides has been about five-fold more active than the stems extract against HHV-1(EC50 40.6+1.6 $\mu \mathrm{g} / \mathrm{mL}$ and $218.1+3.4$ $\mu \mathrm{g} / \mathrm{mL}$, respectively). On the other hand, both leaves and stems extracts have had similar effects against VACV $(37.13+1.3$ and $45.5+2.8 \mu \mathrm{g} / \mathrm{mL}$, respectively) and EMCV (EC50 323.4+5.6 and 377.2+17.7 $\mu \mathrm{g} /$ $\mathrm{mL}$ for leaves and stems, respectively. (Table 2). As shown by HPLC-DAD profiles (Figure 1), mangiferin (1) is the major constituent of both leaves and stems of the A. samydoides specimem we have assayed and might be responsible for the observed antiviral effects. Indeed, mangiferin has previously been shown to be active against both HHV-1 and -2 . The average plaque reduction rate against $\mathrm{HHV}-1$, by the tissue culture technique, was 56.8\% (Zheng \& Lu, 1989). Against HHV-2 the EC50 in HeLa cells was $111.7 \mu \mathrm{g} / \mathrm{mL}$ and at the concentration of $80 \mu \mathrm{g} / \mathrm{mL}$ there was $99 \%$ reduction of the virus replication (Zhu et al., 1993). However, in the present case, this compound has been less potent (EC50 267,9+6.7 $\mu \mathrm{g} / \mathrm{mL}$ ) than the leaves extract (EC50 $40.6+1.6 \mu \mathrm{g} / \mathrm{mL})$ and its EC50 is more close to that one of the stems extract $(218.1+3.4 \mu \mathrm{g} / \mathrm{mL})$. These results are a survey for the presumption that the leaves extract might contain compound(s) more active(s) than mangiferin while it might be the major anti-herpetic constituent of the stems extract. We have shown that mangiferin is less active against VACV (EC50 $182,7+14,3 \mu \mathrm{g} / \mathrm{mL})$ than both the leaves and stems extracts $(37.13+1.3$ and $45.5+2.8 \mu \mathrm{g} / \mathrm{mL}$, respectively) from $A$. samydoides (Table 2) besides being inactive against EMCV. Bioactivity guided fractionation of these extracts has to be carried out looking for minor constituents more active than mangiferin.

Stems extract of Callichlamys latifolia has shown good activity against HHV-1 and VACV (EC50 $30.4+12.0$ and $56.0+4.0 \mu \mathrm{g} / \mathrm{mL}$, respectively ) and a moderate activity against EMCV (EC50 103.0+3.2 $\mu \mathrm{g}$ / $\mathrm{mL})$. It is interesting to notice that the leaves extract has been much less active against HHV-1 and VACV besides being inactive against EMCV (Table 2). As stated
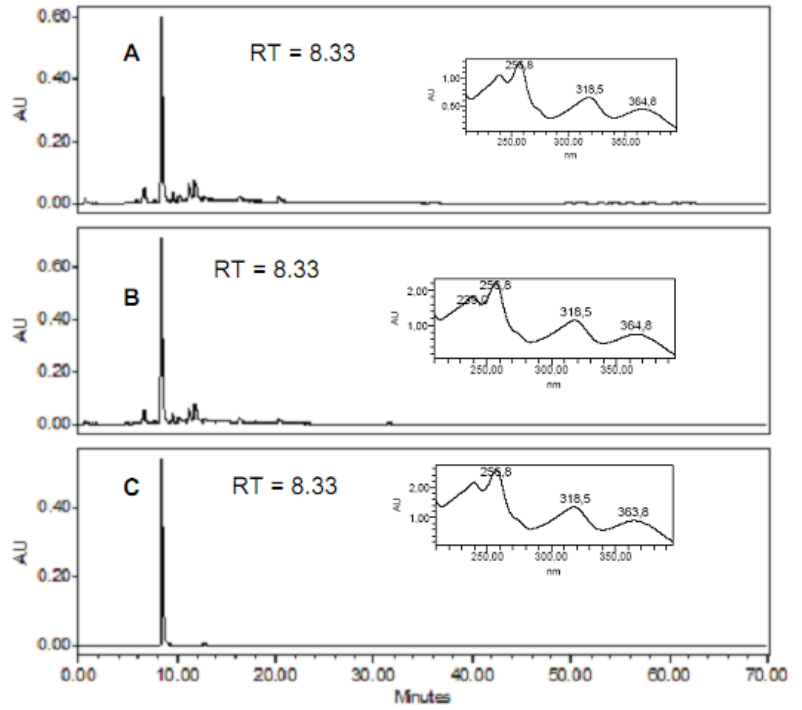

Figure 1. RP-HPLC fingerprints for crude ethanol extracts of Arrabidaea samydoides leaves (A), stems (B), mangiferin (C). Detection $1350 \mathrm{~nm}$. UV spectra on line, $\mathrm{RT}=8.33 \mathrm{~min}$ (mangiferin). Chromatographic conditions: see Materials and Methods.

previously, no data were found on the chemistry and biological activity of $C$. latifolia.

Reported medicinal uses of the seven ethnopharmacologically selected species are shown in Table 3. Only three $(42.8 \%)$ out of these species (Arrabidaea chica, Callichlamys latifolia and Tabebuia impetiginosa) have shown some activity against one or more virus (Table 2). A. chica is a neotropical creeper which occurs, particularly, in the Amazon basin where it is called "pariri", "crajirú", "crajurú" and "carajurú" The leaves of this plant have been widely used by Brazilian indians as dye in body paintings because they produce a dark red pigment that is known as "carajurin". A. chica leaves are nowadays widely used in Northern Brazil to treat blood disfunction (anaemia, hemorrhage), uterine inflammation, hemorrhoids and skin affections (Barbosa et al., 2008). Despite the wide use of this species there are few informations on the pharmacological effects of their leaves. Chemically, 3-deoxyanthocynidins and flavones have been isolated and carajunin was shown to be 6,7dihydroxy-5,4'-dimethoxy-flavylium (Takemura, et al., 1995; Zorn et al., 2001; Devia et al., 2002; Barbosa et al., 2008). The antifungal activity of $A$. chica ethanol extract against Trychophyton mentagrophytes in vitro has been demonstrated (Barbosa et al., 2008) as well the in vitro and in vivo wound healing effects (Jorge et al., 2008).

Tabebuia impetiginosa (synon. T. avellanedae) is a neotropical tree that occurs in Mexico, Central and South America and is popularly known as "ipêroxo", "ipê-preto", "pau-d'arco," "peúva" (Lohmann, 2006), "lapacho" and "taheebo". (Wagner \& Seitz 


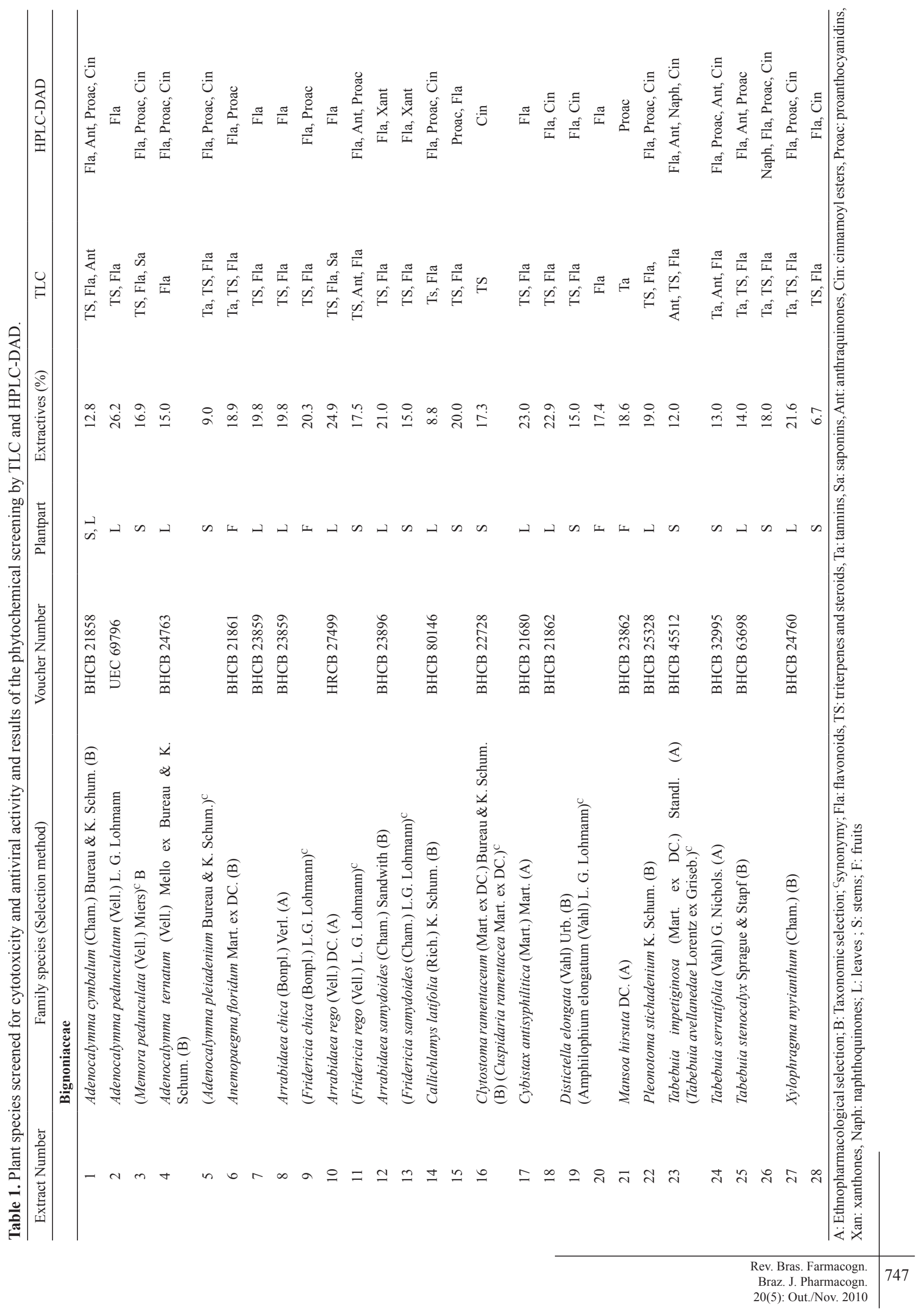


Table 2. Cytotoxicity and antiviral activity of ethanol extracts from Brazilian Bignoniaceae species collected in the state of Minas Gerais.

\begin{tabular}{|c|c|c|c|c|c|c|c|c|c|}
\hline $\begin{array}{l}\text { Extract } \\
\text { Number }\end{array}$ & Family species & Plant part & $\begin{array}{l}\text { VER0 Cells } \\
\text { CC50 }(\mu \mathrm{g} / \mathrm{mL})\end{array}$ & $\begin{array}{c}\text { HHV-1 } \\
\text { EC50 }(\mu \mathrm{g} / \mathrm{mL})\end{array}$ & SI & $\begin{array}{c}\text { VACV-WR } \\
\text { EC50 }(\mu \mathrm{g} / \mathrm{mL})\end{array}$ & SI & $\begin{array}{c}\text { EMCv } \\
\text { EC50 }(\mu \mathrm{g} / \mathrm{mL})\end{array}$ & SI \\
\hline & Bignoniaceae & & & & & & & & \\
\hline 1 & $\begin{array}{l}\text { Adenocalymma } \\
\text { cymbalum }(\mathrm{B})\end{array}$ & $\mathrm{L}, \mathrm{S}$ & $>500$ & NA & & NA & & NA & \\
\hline 2 & A. pedunculatum (B) & $\mathrm{L}$ & $>500$ & $272.5+4.7$ & $>1.8$ & $48.3+1.6$ & $>10.4$ & NA & \\
\hline 3 & & S & $>500$ & NA & & NA & & $374.2+13.9$ & \\
\hline 4 & A. ternatum (B) & $\mathrm{L}$ & $390.9+11.4$ & NA & & NA & & NA & \\
\hline 5 & & S & $>500$ & NA & & $8.1+0.4$ & $>61.6$ & NA & \\
\hline 6 & A. floridum (B) & $\mathrm{F}$ & $>500$ & $266.5+2.9$ & $>1.9$ & $303.8+23.8$ & $>1.6$ & NA & \\
\hline 7 & Arrabidaea chica (A) & $\mathrm{L}$ & $>500$ & $245.7+37.1$ & $>2.0$ & $86.3+2.5$ & $>5.8$ & NA & \\
\hline 8 & & $\mathrm{~F}$ & $>500$ & $303.4+6.3$ & $>1.6$ & $72.4+2.7$ & $>6.9$ & NA & \\
\hline 9 & & S & $426.3+12,2$ & NA & & NA & & NA & \\
\hline 10 & A. rego (A) & $\mathrm{L}$ & $>500$ & NA & & NA & & NA & \\
\hline 11 & & $\mathrm{~S}$ & $>500$ & NA & & NA & & NA & \\
\hline 12 & A. samydoides $(\mathrm{B})$ & $\mathrm{L}$ & $>500$ & $40.6+1.6$ & $>12.3$ & $37.13+1.3$ & $>13.5$ & $323.4+5.6$ & $>1.5$ \\
\hline 13 & & S & $>500$ & $218.1+3.4$ & $>2.3$ & $45.5+2.8$ & $>11.0$ & $377.2+17.7$ & $>1.3$ \\
\hline 14 & $\begin{array}{l}\text { Callichlamys latifolia } \\
\text { (A) }\end{array}$ & $\mathrm{L}$ & $>500$ & $312.3+10.9$ & $>1.6$ & $150.2+2.3$ & $>3.3$ & NA & \\
\hline 15 & & S & $>500$ & $30.4+12.0$ & $>16.5$ & $56.0+4.0$ & $>8.9$ & $103.0+3.2$ & $>4.9$ \\
\hline 16 & $\begin{array}{l}\text { Clytostoma } \\
\text { ramentaceum (B) }\end{array}$ & $\mathrm{S}$ & $19.7+2.8$ & NA & & NA & & NA & \\
\hline 17 & $\begin{array}{l}\text { Cybistax } \\
\text { antisyphilitica }(\mathrm{A})\end{array}$ & $\mathrm{L}$ & $>200$ & NA & & NA & & NA & \\
\hline 18 & $\begin{array}{l}\text { Distictella elongata } \\
\text { (B) }\end{array}$ & $\mathrm{L}$ & $163.3+3.4$ & NA & & $4.6+0.3$ & 36.7 & NA & \\
\hline 19 & & $\mathrm{~S}$ & $>500$ & NA & & $24.3+1.8$ & $>20.6$ & NA & \\
\hline 20 & & $\mathrm{~F}$ & $>500$ & NA & & NA & & NA & \\
\hline 21 & Mansoa hirsuta (A) & $\mathrm{F}$ & $>500$ & NA & & NA & & NA & \\
\hline 22 & $\begin{array}{l}\text { Pleonotoma } \\
\text { stichadenium (B) }\end{array}$ & $\mathrm{L}$ & $19.6+0.5$ & NA & & NA & & NA & \\
\hline 23 & $\begin{array}{l}\text { Tabebuia impetiginosa } \\
\text { (A) }\end{array}$ & $\mathrm{S}$ & $>200$ & $166.6+9.8$ & $>1.2$ & NA & & NA & \\
\hline 24 & T. serratifolia (A) & S & $>500$ & NA & & NA & & NA & \\
\hline 25 & T. stenocalyx (B) & $\mathrm{L}$ & $>500$ & NA & & NA & & NA & \\
\hline 26 & & S & $>500$ & NA & & NA & & NA & \\
\hline 27 & $\begin{array}{l}\text { Xylophragma } \\
\text { myrianthum (B) }\end{array}$ & $\mathrm{L}$ & $>500$ & NA & & NA & & NA & \\
\hline \multirow[t]{3}{*}{28} & & $\mathrm{~S}$ & $>500$ & NA & & $34.1+0.6$ & $>14.7$ & NA & \\
\hline & Acyclovir & & & 40 & & & & & \\
\hline & $\alpha$-2a-Interferon & & & & & $2.5 \times 10^{2}$ & & $1.5 \times 10^{2}$ & \\
\hline
\end{tabular}

CC50: $50 \%$ cytotoxic concentration $(\mu \mathrm{g} / \mathrm{mL})$ for vero cells; EC50: effective concentration $(\mu \mathrm{g} / \mathrm{mL})$ required to inhibit by $50 \%$ the cytopathic effect (CPE) at a viral title of $2.5 \times 10^{6}, 1.0 \times 10^{6}$ and $1.0 \times 10^{6} \mathrm{TCID} 100 / \mathrm{mL}$ for HHV-1, VACV-WR and EMCV respectively; SI: selectivity index = CC50/EC50; HHV - 1: Human herpesvirus 1; EMCV: murine Encephalomiocarditis virus; VACV- WR: Vaccinia virus Western Reserve; NA: Not Active; NT: Not Tested; L: leaves; S: stems; F: fruits.

1998). Ethnopharmacological data point to the use by Southamerican natives for thousand of years. Spanish and Portuguese conquerors described the use of large quantities by indigenous tribes. However, it was only after spreading news on the antitumoral effect of inner bark decoction in the 1960 s that scientific research has greatly increased around the world. Clinical assays of lapachol by the NCI led to its rejection as effective anticancer agent in 1970 and, more recently, the interest has turned to $\beta$-lapachone that revealed significant activity against a range of human tumour cell lines. It has been observed that $\beta$-lapachone, as camptothecin, inhibits 
Table 3. Reported medicinal uses for some of the plant species assayed for cytotoxicity and antiviral activity

\begin{tabular}{|c|c|c|c|}
\hline Plants & Brazilian names & Traditional uses & References \\
\hline \multicolumn{4}{|l|}{ Bignoniaceae } \\
\hline Arrabidaea chica & Carajurú, crajurú, crajirú & $\begin{array}{l}\text { Anti-inflammatory, astringent, } \\
\text { intestinal colic, diarrhea, } \\
\text { leucorrhoea, anemia, leukemia, } \\
\text { skin affections, wound healing }\end{array}$ & Correa, 1975; Cruz, 1985 \\
\hline A. rego & Cipó-rego & Skin affections, gonorrhea & Correa, 1975; Cruz, 1985 \\
\hline Callichlamys latifolia & Cipó-guachana amarelo & Intestinal colic, skin affections & $\begin{array}{l}\text { Cerón-Martínez and Montalvo- } \\
\text { Ayala, 1998; Ríos et al., } 2007\end{array}$ \\
\hline Cybistax antisyphilitica & Ipê-verde, cinco-folhas & $\begin{array}{l}\text { Diaphoretic, syphilis, anti- } \\
\text { edemic, bladder disfuntion }\end{array}$ & Correa, 1975; Cruz, 1985 \\
\hline Mansoa hirsuta & Alho-bravo & Diabetes, throat pains & $\begin{array}{l}\text { Emperaire, 1983; Agra et al., } \\
2007\end{array}$ \\
\hline Tabebuia impetiginosa & Ipê-roxo, pau-d'arco, peúva & $\begin{array}{l}\text { Cancer, liver diseases, skin } \\
\text { affections, inflammations of } \\
\text { the ear and mucosa (gingival, } \\
\text { throat, vagina, uterus and anus), } \\
\text { ovaries, prostate and muscle }\end{array}$ & $\begin{array}{l}\text { Emperaire, 1983; Cruz, 1985; } \\
\text { Agra et al., } 2007\end{array}$ \\
\hline T. serratifolia & Ipê-amarelo, pau-d'arco amarelo & $\begin{array}{l}\text { The same indications and uses } \\
\text { as above }\end{array}$ & Correa, 1975; Agra et al., 2007 \\
\hline
\end{tabular}

topoisomerase I but by a different metabolic pathway. Synthtetic $\beta$-lapachone (ARQ501) is in clinical trials as anticancer at ArQule, USA (Gómez-Castellanos et al., 2009). The bark and heartwood extracts, particularly those in methanol or etanol, are reported to contain lapachol, $\alpha$ - and $\beta$-lapachone, furanonaphthoquinones, lignans and iridoids along with simple aromatic compounds (Warashina et al., 2006, Wagner \& Seitz, 1998). As far as we are concerned this is first report on the evaluation of an ethanol extract from T. impetiginosa against HHV-1, VACV and EMCV. We have detected lapachol, but not $\beta$-lapachone, by HPLC-DAD, in the ethanol extract which was presently assayed.

Six of the eleven taxonomically selected Bignoniaceae species (54.5\%) have shown some activity in one or more virus species (Table 2). Among these Distictella elongata leaves extract has shown the lowest EC50 value $(4.6+0.3 \mu \mathrm{g} / \mathrm{mL}$, against VACV) of the 28 extracts assayed and its chromatographic profile revealed the presence of flavonoids and cinnamoyl esters (Table 1) that might be responsible for the significative antiviral activity observed.

\section{CONCLUSIONS}

Fourteen $(50 \%)$ of the assayed extracts have shown antiviral activity against one or more of the virus and ten of the fourteen active extracts might be considered promising sources of antiviral compounds, as they showed EC $50<100 \mu \mathrm{g} / \mathrm{mL}$. Arrabidaea samydoides is one of the two species, among the eighteen tested ones, to inhibit the replication of the three virus assayed and it is a rich source of mangiferin, an anti-herpetic $C$-glucosylxanthone. This is the first report on the antiviral activity of the eighteen screened species and the results demonstrate the high potential of Bignoniaceae species as source of antiviral agents.

\section{ACKNOWLEDGEMENTS}

To CNPq (Brazil) for financial support and research fellowships (ABO and EGK) and to FAPEMIG (Brazil) for a Doctorate fellowship (GCB).

\section{REFERENCES}

Agra MF, Silva KN, Basílio IJLD, Freitas PF, Barbosa-Filho JM 2007. Synopsis of the plants known as medicinal and poisonous in Northeast of Brazil. Rev Bras Farmacogn 17: 114-140.

Barbosa WLR, Pinto LN, Quignard E, Vieira JMV, Silva Jr. JOC, Albuquerque S 2008. Arrabidaea chica (HBK) Verlot: phytochemical approach, antifungal and trypanocidal activities. Rev Bras Farmacogn 18: 544-548.

Betancur-Galvis LA, Morales GE, Forero JE, Roldan J 2002. Cytotoxic and antiviral activities of colombian medicinal plant extracts of the Euphorbia genus. Mem I Oswaldo Cruz 97: 541-546.

Butler MS 2005. Natural products to drugs: natural product derived compounds in clinical trials. Nat Prod Rep 22: 162-195.

Chattopadhyay D, Naik TN 2007. Antivirals of ethnomedicinal origin: structure-activity relationship and scope. MiniRev. Med Chem 7: 275-301.

Correa MP 1975. Dicionário das plantas úteis do Brasil e das exóticas cultivadas. Instituto Brasileiro de Desenvolvimento Florestal, Rio de Janeiro. V. 6, pp. 777 . 
Cruz GL 1985. Dicionário das plantas úteis do Brasil. 3a. ed. Civilização Brasileira. Rio de Janeiro. pp. 600.

De Clercq E 2001. Vaccinia virus inhibitors as a paradigm for the chemotherapy of poxvirus infections. Clin Microbiol Rev 14: 382-397.

Devia B, Llabres G, Wouters J, Dupont L, Escribano-Bailon MT, Pascual-Teresa S, Angenot L, Tits M 2002. New 3-deoxyanthocyanidins from leaves of Arrabidaea chica. Phytochem Anal 13: 114-120.

Emperaire L. 1983. La Caatinga du sud-est du Piaui (Brésil): Étude Ethnobotanique. Éd. Recherche sur les Civilisations, Paris. pp. 135.

Franco GR, Carvalho AF, Kroon EG, Lovagie S, Werenne J, Golgher RR, Ferreira PC, Bonjardim CA 1999. Biological activities of a human amniotic membrane interferon. Placenta 20: 189-196.

Gentry AH 1992. A synopsis of Bignoniaceae ethnobotany and economic botany. Ann Missoury Bot Garden 79: 53-64.

Gibbons S 2003. An overview of plant extracts as potential therapeutics. Exp Op Ther Pat 13: 489-497.

Gómez-Castellanos JRG, Prieto JM, Heinrich M 2009. Red Lapacho (Tabebuia impetiginosa) - A global ethnopharmacological commodity? J Ethnopharmacol 121: 1-13.

Gómez-Zaleta B, Ramirez-Silva MT, Gutiérrez A, GonzalezVergara E, Güizado-Rodriguez M, Rojas-Hernandez A 2006. UV-vis, ${ }^{1} \mathrm{H}$, and ${ }^{13} \mathrm{C}$ NMR spectroscopic studies to determine mangiferin $\mathrm{pKa}$ values. Spectrochim Acta Part A 64: 1002-1009.

Jorge MP, Madjarof C, Gois Ruiz AL, Fernandes AT, FerreiraRodrigues RA, Sousa IMO, Foglio MA, Carvalho JE 2008. Evaluation of wound healing properties of Arrabidaea chica Verlot extract. J Ethnopharmacol 118: 361-366.

Khan MTH, Ather A, Thopmson K, Gambari R 2005. Extracts and molecules from medicinal plants against herpes simplex viruses. Antiviral Res 67: 107-119.

Lohmann LG 2007. Callichlamys latifolia (Rich.) K. Schum. Flora Brasiliensis Revisitada. http://flora.cria.org.br/ taxonCard?id=FBR416. Acessed on 28/09/2009.

Lohmann LG 2006. Tabebuia impetiginosa (Mart.ex DC.) Standl. Flora Brasiliensis Revisitada. http://flora. cria.org.br/taxonCard?id=FBR2147. Acessed on 28 September 2009.

Mujtaba MG, Patel CB, Patel RA, Flowers LO, Burkhart MA, Waiboci LW, Martin J, Haider MI, Ahmed CM, Johnson MH 2006. The gamma Interferon (IFN- $\gamma$ ) mimetic peptide IFN- $\gamma(95-133)$ prevents Encephalomyocarditis Virus infection both in tissue culture and in mice. Clin Vaccine Immuno 13: 944-952.

Newman DJ, Cragg GM, 2007. Natural products as sources of new drugs over the last 25 years. J Nat Prod 70: 461477.

Oberste MS, Blair EPG, Nix AW, Ksiazek TG, Comer JA, Rollin P, Goldsmith CS, Olson J, Kochel TJ 2009. Human febrile illness caused by Encephalomyocarditis
Virus infection, Peru. Emerging Inf Dis 5: 640-646.

Oliveira AB, Raslan DS, Miraglia MCM, Mesquita AAL, Zani CL, Ferreira DT, Maia JGS 1990. Estrutura química e atividade biológica de naftoquinonas de Bignoniáceas brasileiras. Quim Nova 13: 302-307.

Pauletti PM, Gamboa IC, Silva DHS, Young MCM, Tomazela DM, Eberlin MN, Bolzani VS 2003. New antioxidant $C$-glucosylxanthones from the stems of Arrabidaea samydoides. J Nat Prod 66: 1384-1387.

Reid WV, Laird SA, Meyer CA, Gámez R, Sittenfeld A, Janzen D, Gollin MA, Juma C 1996. Biodiversity prospecting. In: Balick MJ, Elisabetsky E, Laird SA (Eds) Medicinal resources of the tropical forest. Biodiversity and its importance to human health. New York: Columbia University Press, p. 142-173.

Ríos M, Koziol MJ, Pedersen HB, Granda G 2007. Plantas útiles del Ecuador: aplicaciones, retos y perspectivas. Quito: ABYA YALA, pp. 652.

Schulz PV, Hänsel R, Tyler VE 2001. Rational phytotherapy: a physician's guide to herbal medicine. Berlin: SpringerVerlag, pp. 383.

Takemura OS, Iinuma M, Tosa HH, Miguel OG, Moreira EA, Nozawa Y 1995. A flavone from leaves of Arrabidaea chica f. cuprea. Phytochemistry 38: 1299-1300.

Trindade GS, Drumond BP, Guedes MIMC, Leite JA, Mota BEF, Campos MA, Fonseca FGF, Nogueira ML, Lobato ZIP, Bonjardim CA, Ferreira PC, Kroon EG 2007. Zoonotic vaccinia virus infection in Brazil: clinical description and implications for health professionals. J Clin Microb 45: 1370-1372b.

Twentyman PR, Luscombe M 1987. A study of some variables in a tetrazolium dye (MTT) based assay for cell growth and chemosensitivity. Br J Cancer 56: 279-285.

Wagner H, Seitz R 1998. Lapacho (Tabebuia impetiginosa): Poträt einer südamerikanishen Urwalddroge. Zeitsch Phytother 19: 226-238.

Warashina T, Nagatani Y, Noro T 2006. Constituents from the bark of Tabebuia impetiginosa. Chem Pharm Bull 54: 14-20.

Zheng MS, Lu ZY 1989. Antiviral effect of mangiferin and isomangiferin on Herpes simplex virus. Acta Pharmacol Sinica 10: 85-90.

Zhu XM, Song JX, Huang ZZ, Wu YM, Yu MJ 1993. Antiviral activity of mangiferin against Herpes simplex virus type 2 in vitro. Acta Pharmacol Sinica 14: 452-454.

Zorn B, García-Piñeres AJ, Castro V, Murillo R, Gerardo Mora G, Merfort I 2001. 3-Deoxyanthocyanidins from Arrabidaea chica. Phytochemistry 56: 831-835.

"Part of GC Brandão's Doctorate Thesis at the Programa de Pós-graduação em Ciências Farmacêuticas, Faculdade de Farmácia, Universidade Federal de Minas Gerais, Belo Horizonte-MG, Brazil. 